\title{
Changes in the biochemical characteristics and volatile fingerprints of atemoya during postharvest ripening at room temperature
}

\author{
Xiao Gong ${ }^{1,2}$, Xianshao $\mathrm{Wu}^{3}$, Ningli Qi ${ }^{1}$, Jihua $\mathrm{Li}^{1,2, *}$, Hao Zhang ${ }^{4}$, Yujia Huo ${ }^{4}$ \\ ${ }^{1}$ Key Laboratory of Tropical Crop Products Processing of Ministry of Agriculture and Rural Affairs, Agricultural Products \\ Processing Research Institute, Chinese Academy of Tropical Agricultural Sciences, Zhanjiang, China; ${ }^{2}$ Hainan Key \\ Laboratory of Storage \& Processing of Fruits and Vegetables, Zhanjiang, China; ${ }^{3}$ Grain and Oil Quality Inspection Center \\ of Guangxi Zhuang Autonomous Region, Nanning, China; ${ }^{4}$ G.A.S. Department of Shandong Hanon Instruments Co., Ltd., \\ Jinan, China
}

*Corresponding Author: Jihua Li, Key Laboratory of Tropical Crop Products Processing of Ministry of Agriculture and Rural Affairs, Agricultural Products Processing Research Institute, Chinese Academy of Tropical Agricultural Sciences, Zhanjiang, 524001, China. Email: foodpaper@126.com

Received: 09 July 2020; Accepted: 28 September 2020; Published: 16 October 2020

(C) 2020 Codon Publications

\section{OPEN ACCESS CC(1)(2) ORIGINAL ARTICLE}

\begin{abstract}
In order to determine the best shelf life of the atemoya, the changes in the biochemical characteristics in five different stages of senescence were investigated. During postharvest ripening at room temperature, the firmness decreased rapidly after harvest and the fruit weight loss and browning degree increased from the earliest green-colored stage onward. The total soluble solid concentrations (TSSC) and titratable acidity (TA) increased continuously throughout maturation, and the peak respiratory and ethylene production rates occurred on the $3 \mathrm{~d}$ and 5th day of postharvest, respectively. Phenylalanine ammonia-lyase (PAL) activity steadily increased, catalase and polyphenol oxidase (PPO) activities decreased significantly on the 1st day and then gradually increased, and peroxidase activities increased during the initial 3 days, and then decreased at later stages. The volatile fingerprints of flesh samples from the five senescence stages were successfully established using gas chromatography-ion mobility spectrometry (GC-IMS) combined with principal component analysis, and 32 typical target compounds and 35 indeterminate compounds were obtained. The results provide a theoretical basis for the development of innovative preservation methods for atemoya.
\end{abstract}

Keywords: biochemical changes; headspace-gas chromatography-ion mobility spectrometry; postharvest characteristics; volatile organic compounds

\section{Introduction}

Annona includes one of the world's most famous fruit, atemoya, which has creamy white pulp, and low acidity. The genus, which belongs to the family Annonaceae, is composed of over 100 species; however, only five (Annona squamosa, A. cherimola, A. muricata, A. reticulata, and $A$. atemoya) are of significant commercial importance (Pareek et al., 2011). Because of their taste and high nutritional value, including carbohydrates, amino acids, lipids, vitamins (A, B, and $\mathrm{C}$ ), fiber, and minerals (Fe, $\mathrm{Ca}, \mathrm{Mg}$, and P), Annona spp. are considered valuable for table purposes, and have been commercially cultivated in subtropical and tropical regions of the world in recent decades (Hiwale, 2015; Pareek et al., 2011).

Atemoya is a hybrid of A. squamosa and A. cherimola, and is normally heart-shaped or round, weighs approximately 300-500 g, and has pale green, bumpy skin. The majority of the skin is as bumpy as that of the sugar 
apple, but it becomes smoother, like the cherimoya, at its base. The flesh is not segmented like that of the sugar apple, bearing more similarity to that of the cherimoya. It is very juicy and smooth, tasting slightly sweet with good flavor (Horticulture Innovation, 2019; Wade, 2009). To date, it has been widely cultivated, including in India, Cuba, Venezuela, Israel, Lebanon, Australia, and Taiwan. In 2002, the fruit was successfully introduced to Mainland China from Taitung City in Taiwan, and started cultivation at large scale in tropical China (Fang et al., 2015). However, atemoya is a typical climacteric fruit with the following characteristics: it is highly perishable, usually softens very rapidly, and browns and cracks during ripening. Thus, reducing its commercial and edible value and limiting its cold chain distribution and circulation. The Food and Agriculture Organization of the United Nations (FAO) has reported vegetable and fruit losses in developing countries of up to $40-50 \%$ annually. Approximately, $16 \%$ of which is due to poor postharvest handling and storage, and in particular, cooling chain limitations in agricultural production storage and distribution activities (Gustavsson et al., 2011).

Information on the biochemical properties and aroma profiles of atemoya during postharvest ripening at room temperature is very limited. The objective of this work was to investigate changes in the biochemical properties and volatile compounds of atemoya fruit during postharvest ripening. The expected results are to provide a theoretical basis for determining consumer acceptance and developing innovative preservation methods for atemoya fruit.

\section{Materials and Methods}

\section{Materials and reagents}

"Gefner" atemoya ( $A$. cherimola $\times$ A. squamosa) fruit with skin firmness of 30-40 N were harvested at commercial maturity from Chongguan ridge $\left(22^{\circ} 21^{\prime} \mathrm{N}\right.$ and $\left.107^{\circ} 33^{\prime} \mathrm{E}\right)$ in Guangxi, China in September 2018. They were handpicked and packed in cooler boxes, and transported to the laboratory within $4 \mathrm{~h}$ of harvest. The atemoya variety was identified by Prof. Yiji Kong from the South Subtropical Crops Research Institute, Chinese Academy of Tropical Agricultural Sciences. Fruit that were uniformly shaped (350 $\pm 50 \mathrm{~g}$ each) and free of defects and cracks were selected for analysis. A total of 120 fruit were divided into two lots and stored at ambient conditions for natural maturity. The maturity stage was judged by the surface color and softness, and five stages were selected, as shown in Figure 1.

\section{Firmness determination}

Firmness was measured on two opposing sides of each atemoya $(n=6)$ using a GY-4 Digital Fruit Hardness Tester (Zhiqu Co. Ltd., Dongguan, China) with a 5-mm diameter probe, at a speed of $1 \mathrm{~mm} \mathrm{~s}^{-1}$ and a load range of $200 \mathrm{~N}$. The compression force was recorded at the maximum transverse diameter of the fruit and the probe was directed perpendicularly to the fruit. The results are expressed in $\mathrm{N}$.

\section{Fruit mass loss (FML) and browning degree (BD) measurements}

The fruit mass loss (FML) was calculated as the percent reduction from the initial weight. And the browning degree (BD) was assessed by evaluating the extent of the browned area on the fruit surface, as previously reported by Ali et al. (2016).

\section{Respiratory and ethylene production rate measurements}

The respiratory rate of atemoya fruit was determined using a breath analyzer (SY-1022, Liaoning Andreas Technology Co., Liaoning, China), and the results are expressed in $\mathrm{mg} \mathrm{CO}_{2} \mathrm{~kg}^{-1} \mathrm{~s}^{-1}$. Ethylene production was measured as described by Huan et al. (2018) with some modifications. Briefly, at each time point, three fruit per group were randomly selected and enclosed in $5.0 \mathrm{~L}$

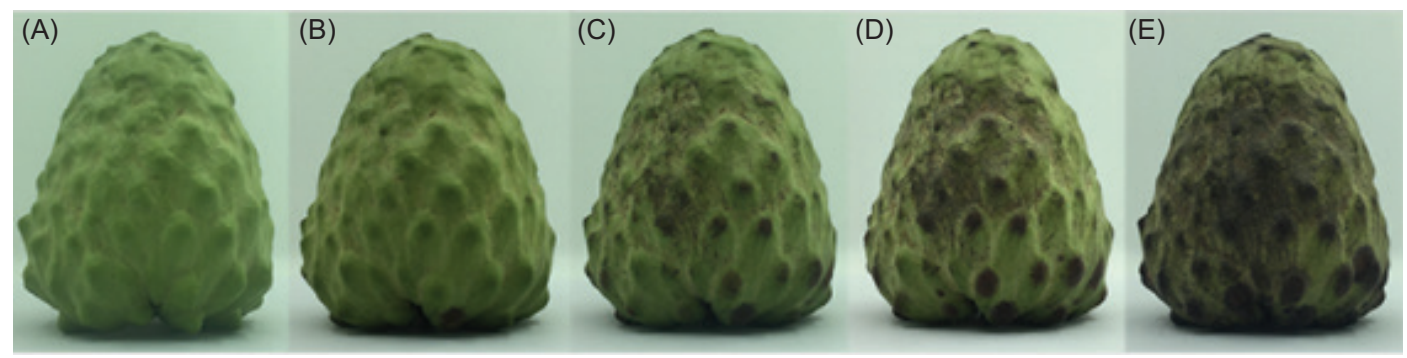

Figure 1. Five stages of postharvest atemoya fruit senescence. (A) at harvest, (B) 1d, (C) 3d, (D) 5d, (E) 7d 
glass jars at $25^{\circ} \mathrm{C}$ for $1 \mathrm{~h}$, and $1 \mathrm{~mL}$ of headspace gas was injected into a gas chromatographer (GC7890A, Agilent Technologies, Chandler, AZ, USA) coupled to an FID detector. The injector, column, and detector temperatures were 50,50 , and $150^{\circ} \mathrm{C}$, respectively. Ethylene values are expressed as $\mathrm{ng}_{2} \mathrm{C}_{4} \mathrm{~kg}^{-1} \mathrm{~s}^{-1}$.

\section{Total soluble solid concentrations (TSSC) and titratable acidity (TA) measurements}

Each atemoya $(\mathrm{n}=3)$ was sliced and rapidly frozen in liquid nitrogen vapor, and then stored at $-40^{\circ} \mathrm{C}$ prior to analysis. Frozen tissues $(50 \mathrm{~g})$ were thawed at $4{ }^{\circ} \mathrm{C}$ for $3 \mathrm{~h}$, and then homogenized in a blender (Thermo Fisher Scientific, MA, USA). The soluble solid concentrations (TSSC) values were determined using an Atago PAL-1 digital refractometer (Atago Co. Ltd., Tokyo, Japan). The titratable acidity (TA) was measured by diluting $10 \mathrm{~g}$ of pulp in $100 \mathrm{~mL}$ of double-distilled $\mathrm{H}_{2} \mathrm{O}$ and titrating to pH 7.0 with $0.01 \mathrm{~mol} \mathrm{~L}^{-1} \mathrm{NaOH}$, and is expressed as the percentage of citric acid.

\section{Total phenol and lignin content measurements}

Total phenols were measured with Folin-Ciocalteu reagent according to the method described by Chu et al. (2018), and the results are expressed as $\mathrm{OD}_{280} \mathrm{~g}^{-1}$ sample. Lignin was extracted and determined as reported by Bruce and West (1989). Approximately $1 \mathrm{~g}$ of pulp was homogenized in $4 \mathrm{~mL}$ of $95 \%$ ethanol precooled to $0^{\circ} \mathrm{C}$, and centrifuged at $3800 \times g$ for $5 \mathrm{~min}$ at $4^{\circ} \mathrm{C}$. The residue was washed twice with cold ethanol and a mixture of ethanol:n-hexane (1:2). The precipitate was dried for $30 \mathrm{~min}$ at $60^{\circ} \mathrm{C}$ and was dissolved in $2 \mathrm{~mL}$ of $25 \%$ acetyl bromide-glacial acetic acid solution. The sample was incubated at $70^{\circ} \mathrm{C}$ in a shaking water bath for $30 \mathrm{~min}$ and then $1 \mathrm{~mL}$ of $2 \mathrm{~mol} \mathrm{~L}^{-1} \mathrm{NaOH}$, $1 \mathrm{~mL}$ of acetic acid, and $0.1 \mathrm{~mL}$ of hydroxylamine hydrochloride were added successively. The volume was brought to $5 \mathrm{~mL}$ with acetic acid and the $\mathrm{OD}_{280}$ was measured.

\section{Enzyme activity assays}

To determine enzyme activities, atemoya tissue $(2 \mathrm{~g})$ was ground with $5 \mathrm{~mL}$ phosphate buffer ( $\mathrm{pH} 7.8)$ containing $40 \mathrm{~g} \mathrm{~L}^{-1}$ crosslinked polyvinylpyrrolidone (PVPP), $2 \mathrm{mmol} \mathrm{L} \mathrm{L}^{-1}$ ethylene diamine tetraacetic acid (EDTA), and $5 \mathrm{mmol} \mathrm{L}^{-1} \beta$-mercaptoethanol in an ice-water bath. The homogenate was centrifuged at $10,000 \times g$ and $4^{\circ} \mathrm{C}$ for $20 \mathrm{~min}$. The obtained supernatant was used as the crude enzyme extract. The phenylalanine ammonia-lyase (PAL) activity was measured according to Koukol and Conn (1961). One unit of PAL activity was defined as the amount of enzyme that caused the increase in absorbance of 0.01 per minute at $290 \mathrm{~nm}$, and the result was expressed as $\mathrm{U} \mathrm{g}^{-1}$ fresh weight. The catalase (CAT) activity was determined as described by Aebi (1984) with slight modifications. $0.1 \mathrm{~mL}$ of enzyme extract was mixed with $1 \mathrm{~mL}$ of $0.1 \mathrm{~mol} \mathrm{~L}^{-1} \mathrm{H}_{2} \mathrm{O}_{2}$ and $2.5 \mathrm{~mL}$ of $0.05 \mathrm{~mol} \mathrm{~L}^{-1}$ phosphate buffer $(\mathrm{pH} 7.8)$. The reaction mixture was determined at $240 \mathrm{~nm}$ at an interval of $30 \mathrm{~s}$ for $3 \mathrm{~min}$. One unit of CAT activity was defined as the amount of enzyme that decreased in absorbance of 0.01 at $240 \mathrm{~nm}$ per minute. The results were expressed in $\mathrm{U} \mathrm{kg}^{-1}$ fresh weight. The polyphenol oxidase (PPO) activity was assayed according to Galeazzi et al. (1981) with some modifications and were extracted from $5 \mathrm{~g}$ frozen tissue with $25 \mathrm{~mL}$ of $0.2 \mathrm{~mol} \mathrm{~L}^{-1}$ sodium phosphate buffer $(\mathrm{pH} 6.5)$ containing $1 \%$ polyvinylpyrrolidone. One unit of PPO activity was defined as the amount of enzyme that caused an increase in the absorbance of 0.01 per minute at $420 \mathrm{~nm}$. The POD activity was determined according to Hammerschmidt and Kuć (1982) with slight modifications. The reaction mixture consisted of $50 \mathrm{mmol} \mathrm{L}^{-1}$ sodium phosphate buffer (pH 6.0), $0.5 \mathrm{~mol} \mathrm{~L}^{-1} \mathrm{H}_{2} \mathrm{O}_{2}, 25 \mathrm{mmol} \mathrm{L}^{-1}$ guaiacol, and $0.1 \mathrm{~mL}$ crude enzyme extract. One unit of peroxidase (POD) activity was defined as the amount of enzyme that caused the increase in absorbance of 0.01 per minute at $470 \mathrm{~nm}$ and the data are expressed in $\mathrm{U} \mathrm{mg}^{-1}$ protein.

\section{Quantification of volatile compounds}

Samples of atemoya fruit were analyzed on a gas chromatography-ion mobility spectrometry (GC-IMS) instrument (FlavourSpec, GAS, Dortmund, Germany) equipped with an autosampler (Hanon Auto SPE 100, Shandong, China) for headspace analysis. Samples $(2.0 \mathrm{~g})$ were weighed into $20 \mathrm{~mL}$ headspace vials $(\mathrm{CNW}$ Technologies, Germany), and then incubated in headspace volume at $60^{\circ} \mathrm{C}$ for $10 \mathrm{~min}$. Headspace $(500 \mu \mathrm{L})$ was automatically loaded into the injector in splitless mode through a syringe heated to $65^{\circ} \mathrm{C}$.

The analytes were separated on a FS-SE-54-CB-1 capillary column $(15 \mathrm{~m} \times 0.53 \mathrm{~mm})$ at a constant temperature of $40^{\circ} \mathrm{C}$ and then ionized in the IMS instrument (FlavourSpec', Gesellschaft für Analytische Sensorsysteme $\mathrm{mbH}$, Dortmund, Germany) at $45^{\circ} \mathrm{C}$. High purity nitrogen gas (99.999\%) was used as the carrier and drift gas, with an initial flow rate of $150 \mathrm{~mL}$ $\mathrm{min}^{-1}$ and the following program was: $2 \mathrm{~mL} \mathrm{~min}^{-1}$ for the first $2 \mathrm{~min}$, then a linear increase to $150 \mathrm{~mL} \mathrm{~min}{ }^{-1}$ over $18 \mathrm{~min}$, then $150 \mathrm{~mL} \mathrm{~min}{ }^{-1}$ for $10 \mathrm{~min}$. Ketones $\mathrm{C}_{4}-\mathrm{C}_{9}$ (Sigma Aldrich, St. Louis, MO) were used as an external standard to determine the retention index (RI) of volatile organic compounds. Analyte identification was performed using the Laboratory Analytical Viewer (LAV) 2.2.1 (GAS, Dortmund, Germany) by comparing RI and the drift time of standard in the GC-IMS Library. 


\section{Statistical data analysis}

All samples were prepared in duplicate and tested at least six times, and the result was expressed as mean \pm standard deviation and the level of statistical significance $(\mathrm{P}<0.05)$ was analyzed by using Tukey's range test of SPSS 18.0 software (SPSS Inc., Chicago, IL, USA). The principal component analysis (PCA) was performed using the LAV software in-built "Dynamic PCA" plug-in to model patter of aroma volatile.

\section{Results and Discussion}

\section{Firmness changes}

Fruit softening is a complex physiological process, which is closely related to postharvest ripening and senescence and plays an important role in determining fruit-flavor quality Chen et al., (2019). In practice, most consumers subjectively estimate fruit firmness by applying a compression force with their fingers. Brown et al. (1988) found that when ripened at $20^{\circ} \mathrm{C}$, atemoya fruit reached acceptable edible quality after the first detectable softening changes. As shown in Table 1, the firmness decreased rapidly from $10.95 \mathrm{~N}$ to $3.26 \mathrm{~N}$ after 1 day of storage in ambient conditions, and then decreased slowly from $3.26 \mathrm{~N}$ to $1.35 \mathrm{~N}$ within the next 6 days in storage. The firmness change corresponded to the softening characteristics of atemoya fruit, and was consistent with a previous report (Zainal et al., 2019). However, details on how the mechanical properties of atemoya fruit change during the ripening process are limited, and how they are affected by postharvest processing is unknown. It has been inferred that the softening of atemoya fruit is not only dependent on the expression of xyloglucan endotransglycosylase and expansion genes, but is also affected by the cultivar, production area, harvest timing, and other factors (Pareek et al., 2011; Shen et al., 2009). Pulp softening and apparent color change during ripening and senescence are two major characteristics affecting the shelf life and market value of postharvest fruit (Lin et al., 2018).

\section{Fruit mass loss and browning degree}

After harvest, respiration is the cause of FML in most horticultural products. For most fruit, FML $\geq 8 \%$ results in a wilted or shriveled appearance, which makes the fruit more perishable and begins to significantly affect its acceptability to consumers (Cruz-Bravo et al., 2019). The FML of postharvest atemoya steadily increased, reaching $8.46 \%$ on the 7 th day under room temperature $(25 \pm$ $3^{\circ} \mathrm{C}$ and $70 \pm 5 \%$ relative humidity). For this reason, we measured the effects of atemoya fruit storage for 7 days. Importantly, atemoya fruit decay is also associated with genotype, maturity, and postharvest handling (Pareek et al., 2011).

The intensity of color development determines the harvest time and ripening duration (Pareek et al., 2011). As shown in Figure 1, atemoya skin color changed from dark green to light green or greenish-yellow through the postharvest ripening process, and visible brown spots were observed on the 3rd day, with 1.41\% BD and acceptable marketability. By the 5th day, more obvious browning occurred, with $15.67 \% \mathrm{BD}$ and limited marketability. By the 7th day, obvious browning was observed, with $>45.49 \% \mathrm{BD}$ and poor sensory acceptability. In practice, the harvesting time and eating quality is commonly determined by the fruit skin color, which changes with physiological maturity.

Table 1. Changes of FML, BD, skin firmness, TSSC, TA, total phenols and respiratory rate, ethylene production, and lignin content of atemoya fruit during postharvest storage.

\begin{tabular}{|c|c|c|c|c|c|}
\hline \multirow[t]{2}{*}{ Factor } & At harvest & 1 day & 3 days & 5 days & 7 days \\
\hline & \multicolumn{5}{|c|}{ Storage time (day) } \\
\hline Firmness (N) & $10.95 \pm 0.31^{e}$ & $3.26 \pm 0.40^{d}$ & $2.63 \pm 0.32^{c}$ & $1.97 \pm 0.25^{b}$ & $1.35 \pm 0.19^{\mathrm{a}}$ \\
\hline FML (\%) & $0^{\mathrm{a}}$ & $1.27 \pm 0.23^{b}$ & $4.39 \pm 0.18^{c}$ & $6.66 \pm 1.02^{d}$ & $8.46 \pm 0.91^{e}$ \\
\hline $\mathrm{BD}(\%)$ & $0^{\mathrm{a}}$ & $0.54 \pm 0.17^{b}$ & $1.41 \pm 0.40^{\circ}$ & $15.67 \pm 1.71^{d}$ & $45.49 \pm 1.72^{\mathrm{e}}$ \\
\hline TSSC (\%) & $13.91 \pm 0.56^{\mathrm{a}}$ & $18.93 \pm 0.79^{b}$ & $19.40 \pm 0.90^{c}$ & $19.65 \pm 1.10^{c}$ & $20.05 \pm 0.79^{d}$ \\
\hline TA ( $\%$ citric acids) & $0.04 \pm 0.02^{\mathrm{a}}$ & $0.05 \pm 0.03^{\mathrm{ab}}$ & $0.06 \pm 0.04^{b}$ & $0.08 \pm 0.05^{c}$ & $0.06 \pm 0.04^{d}$ \\
\hline Respiratory rate $\left(\mathrm{mL} \mathrm{CO} \mathrm{kg}^{-1} \mathrm{~h}^{-1}\right)$ & $317.43 \pm 15.42^{c}$ & $551.95 \pm 25.23^{d}$ & $575.22 \pm 22.01^{e}$ & $307.85 \pm 19.98^{b}$ & $259.91 \pm 32.56^{a}$ \\
\hline Ethylene production rate $\left(\mu \mathrm{L}_{2} \mathrm{H}_{4} \mathrm{~kg}^{-1} \mathrm{~h}^{-1}\right)$ & $0.23 \pm 0.01^{a}$ & $3.98 \pm 0.14^{b}$ & $15.67 \pm 1.8^{c}$ & $34.39 \pm 5.17^{d}$ & $22.38 \pm 3.20^{\mathrm{e}}$ \\
\hline Total phenols $\left(\mathrm{OD}_{280 \mathrm{~nm}} \mathrm{~g}^{-1}\right)$ & $0.64 \pm 0.03^{\mathrm{ac}}$ & $0.93 \pm 0.12^{c}$ & $1.34 \pm 0.08^{d}$ & $0.77 \pm 0.02^{b}$ & $0.77 \pm 0.06^{b}$ \\
\hline Lignin $\left(A_{280} g^{-1}\right)$ & $73.50 \pm 0.13^{a}$ & $74.56 \pm 0.25^{b}$ & $95.05 \pm 0.62^{c}$ & $98.56 \pm 0.70^{d}$ & $124.92 \pm 1.40^{\mathrm{e}}$ \\
\hline
\end{tabular}




\section{Respiratory rate and ethylene production}

Atemoya displays typical climacteric maturation, characterized by an increased respiration rate (Morena and De La Plaza, 1993). Fruit respiration involves the oxidation of organic molecules (e.g., carbohydrates, amino acids, and organic acids) in cells into small molecule metabolites with concurrent energy production, and is closely related to fruit maturity and senescence (Liu et al., 2019). The respiration rates of postharvest atemoya fruit at different senescence stages are shown in Table 1. The respiration rate initially increased rapidly postharvest and then decreased, and the peak respiration rate $(0.23$ $\mathrm{mg} \mathrm{CO} \mathrm{kg}^{-1} \mathrm{~s}^{-1}$ ) occurred on the 3rd day, consistent with the results of Alique and Zamorano (2000). Ethylene production in atemoya fruit increased after harvest and the peak rate (approximately $0.12 \mathrm{mg} \mathrm{CO} \mathrm{kg}^{-1} \mathrm{~s}^{-1}$ ) was detected on the 5th day of storage, after the onset of climacteric respiration, similar to the results of Brown et al. (1988). Moreover, ethylene emission rates were significantly higher in the mature stage $\left(1.33-2.30 \mathrm{ng} \mathrm{C}_{2} \mathrm{H}_{4}\right.$ $\left.\mathrm{kg}^{-1} \mathrm{~s}^{-1}\right)$ than in the immature stage $\left(0.02-0.34 \mathrm{ng} \mathrm{C}_{2} \mathrm{H}_{4}\right.$ $\left.\mathrm{kg}^{-1} \mathrm{~s}^{-1}\right)(\mathrm{P}<0.05)$. Fruit softening during storage is usually triggered by ethylene (Krongyut et al., 2011), and the respiration and ethylene emission rates both depend on the cultivar and maturity stage, and are affected by the temperature and humidity of the harvesting area, as well as other factors (Pareek et al., 2011). For climacteric fruit, delaying the peak respiration rate can help to extend the shelf life.

\section{Total soluble solid concentrations (TSSC) and titratable acidity (TA)}

The total soluble solid concentrations (TSSC), mostly composed of sugars and acids together with small amounts of dissolved compounds, is the most important quality parameter used by the industry to indicate the sweetness of fresh horticultural products and determine marketing standards (Magwaza and Tesfay, 2015). Tietz (1988) found that the flavor development of ripe cherimoya was closely correlated with the TSSC. The TSSC of atemoya fruit increased from approximately 13.91 to $20.05 \%$ during 7 days of postharvest ripening (Table 1). Similar to the TSSC, the TA content is also associated with atemoya taste and sensory properties, and increased acidity can be ascribed to organic acid production during ripening (Gutierrez et al., 1994). Along with increased fruit maturity, we observed a slight increase in acidity during the initial stages of atemoya fruit ripening, followed by a significant decrease $(\mathrm{P}<0.05)$ compared to the initial value $(0.04 \%$ citric acid). This result is consistent with a previous report (Bolivar-Fernandez et al., 2009). Changes in TSSC and TA could be used to measure the process of commercial maturation.

\section{Total phenol and lignin contents}

Phenols, secondary metabolites found in fruit and vegetables, are associated with quality and flavor formation, are precursors for lignin synthesis, and are natural substrates in enzymatic browning reactions (Li et al., 2009). As shown in Table 1, the total phenol content gradually increased from $0.64 \mathrm{OD}_{280} \mathrm{~g}^{-1}$ at harvest to $1.34 \mathrm{OD}_{280} \mathrm{~g}^{-1}$ on the 3rd day, and then decreased during the pulp lignification process, falling to $0.77 \mathrm{OD}_{280} \mathrm{~g}^{-1}$ by the 7 th day.

Lignin is a secondary metabolite in plant tissues, and its accumulation is the key reason for postharvest deterioration in fruit quality. After 7 days of storage, obvious lignin synthesis was observed in atemoya flesh compared with at harvest, and the lignin content increased significantly, from $73.50 \mathrm{OD}_{280} \mathrm{~g}^{-1}$ at harvest to $124.92 \mathrm{OD}_{280} \mathrm{~g}^{-1}$ at day $7(\mathrm{P}<0.05)$. Storage at $4{ }^{\circ} \mathrm{C}$ significantly delayed the lignification process by inhibiting lignin-related enzymes such as PAL and PPO activities (data not shown), resulting in less lignin content. Lignification is among the most important physiological disorders in a wide variety of horticultural products, and is correlated with cell wall metabolism abnormality generated by pectin metabolism, manifesting as a woolly texture with a lack of juiciness, which decreases consumer acceptance (Li et al., 2009; Lin et al., 2018; Suo et al., 2018; Ubi et al., 2016).

\section{Enzyme activity assays}

Figure 2 shows the activity changes in PAL, catalase and polyphenol oxidase, and peroxidase activities during the postharvest ripening of atemoya fruit in ambient conditions. The change in PAL activity correlated with lignin accumulation, and was consistent with results in kiwifruit (Suo et al., 2018). Catalase and polyphenol oxidase activities displayed similar trends, decreasing significantly on the 1st day compared to at harvest, and then gradually increasing during the remaining period. Peroxidase activity oscillated throughout the ripening period. In most cases, enzymatic browning catalyzed by PPO is considered to be one of the most important oxidative reactions in fruit, leading to loss of sensory and nutritional qualities (Ali et al., 2016; Pareek et al., 2011; Zainal et al., 2019).

\section{Volatile compound identification and principal component analysis}

Characteristic volatile fingerprints were obtained by comparing ion mobility spectrometry drift times and relative RIs with those of authentic reference compounds. The changes in volatile compounds in postharvest atemoya fruit at five different senescence stages are presented 


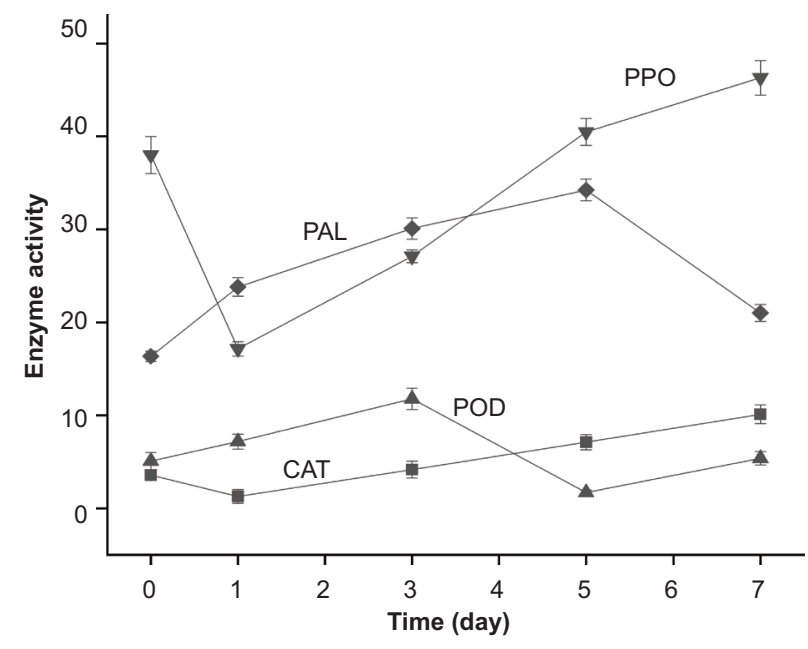

Figure 2. Changes in atemoya fruit enzyme activities during postharvest ripening in ambient conditions (the result was expressed as mean \pm standard deviation, $n=6$ ). as a $3 \mathrm{D}$ topographical visualization in Figure $3 \mathrm{~A}$. The ion migration time and the position of the reactive ion peak (RIP) were normalized, and 3D topographical plots at different stages are shown in Figure 3B. A total of 32 typical target compounds were identified by the $\mathrm{GC} \times$ IMS Library (Table 2) and 35 indeterminate compounds were also obtained. Due to their different concentrations, some single compounds may have produced multiple signals (dimers and multimers).

As shown in Figure 4, the volatile compounds detected in atemoya fruit at the five stages of senescence were similar, and trans-beta-ocimene, beta-pinene, gamma-terpinene, limonene, myrcene, alpha-pinene, alpha-terpineol, linalool, acetone, and ethanol were detected at all stages, with slight differences in signal intensity. Volatile aroma compound composition and content in atemoya fruit changed significantly during postharvest storage. The signal intensities of trans-2-hexenol, 1-pentanol,

(A)

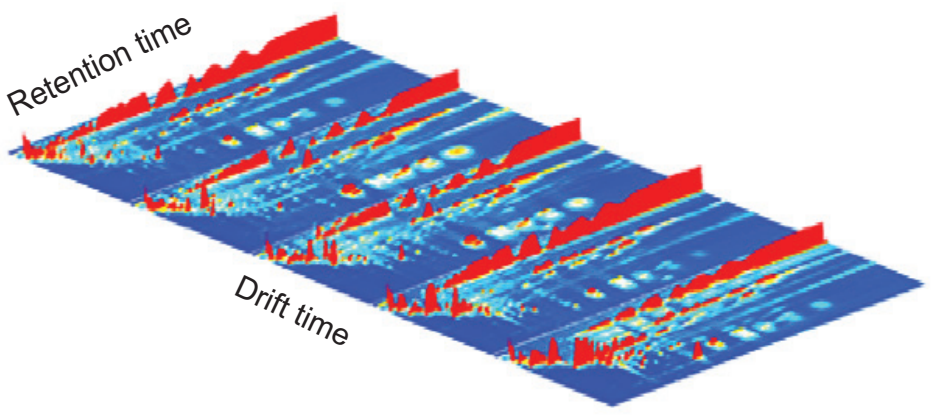

(B) At harvest $1 d$ $3 d$ $5 d$

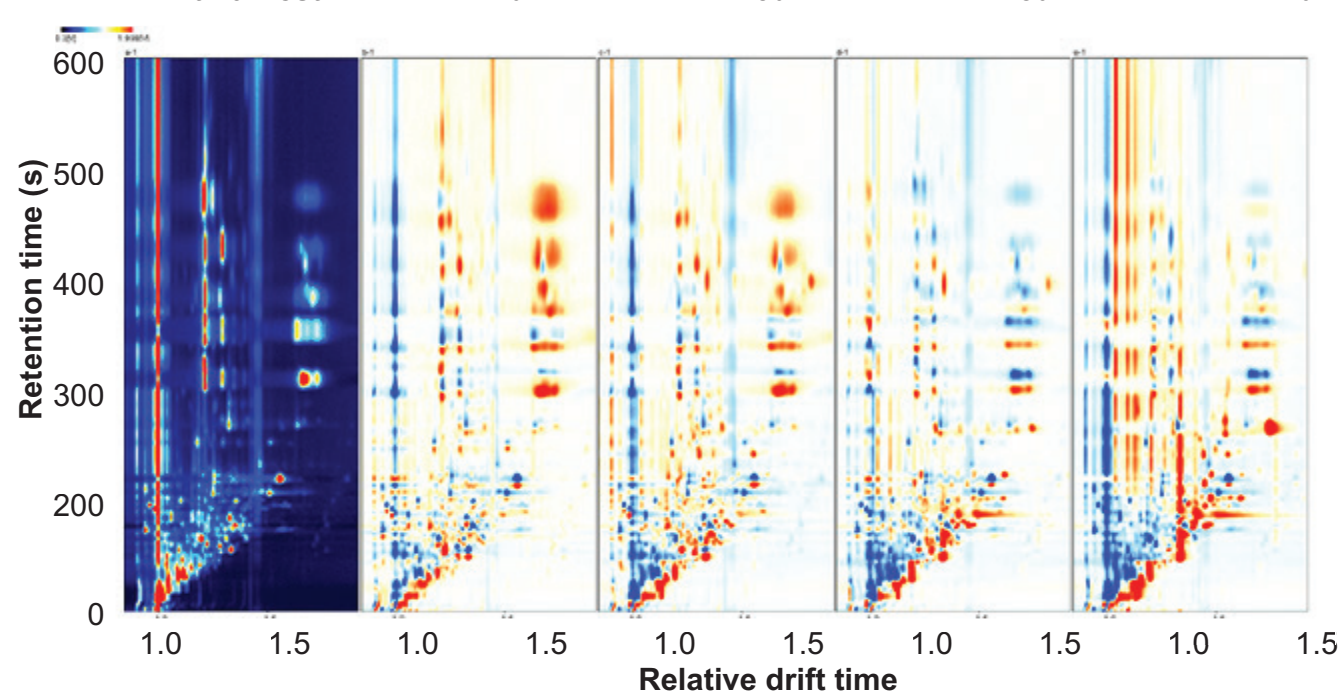

Figure 3. 3D topography of flesh samples of atemoya fruit at five stages of senescence. (A) the $y$-axis represents the GC retention time, the $\mathrm{x}$-axis represents the ion migration time for identification, and the z-axis represents the peak height for quantification. (B) 3D topographical plots at different stages. 
Table 2. GC-IMS integration parameters of volatile compounds of postharvest atemoya fruit.

\begin{tabular}{|c|c|c|c|c|c|c|}
\hline No. & Compound & MW & $\mathrm{Rl}^{\mathrm{a}}$ & $\mathrm{RT}[\mathrm{s}]^{\mathrm{b}}$ & MT [RIPrel] ${ }^{\mathrm{c}}$ & Identification approach \\
\hline 1 & Alpha-terpineol & 154.3 & 1194.8 & 881.652 & 1.2184 & RI, DT \\
\hline 2 & Limonene & 136.2 & 1020.6 & 472.29 & 1.2183 & $\mathrm{RI}, \mathrm{DT}$ \\
\hline 3 & Ethyl hexanoate dimer & 144.2 & 1004.3 & 441.021 & 1.8229 & RI, DT \\
\hline 4 & Ethyl hexanoate & 144.2 & 1004.3 & 441.021 & 1.3429 & $\mathrm{RI}, \mathrm{DT}$ \\
\hline 5 & Trans-beta-ocimene & 136.2 & 1045.5 & 525.124 & 1.2143 & RI, DT \\
\hline 6 & Myrcene & 136.2 & 991.3 & 418.245 & 1.217 & RI, DT \\
\hline 7 & Beta-pinene & 136.2 & 968.2 & 382.971 & 1.217 & $\mathrm{RI}, \mathrm{DT}$ \\
\hline 8 & Alpha-pinene & 136.2 & 928.6 & 334.924 & 1.2155 & $\mathrm{RI}, \mathrm{DT}$ \\
\hline 9 & 3-Methylbutyl acetate dimer & 130.2 & 879.3 & 289.918 & 1.7444 & $\mathrm{RI}, \mathrm{DT}$ \\
\hline 10 & 3-Methylbutyl acetate & 130.2 & 880.1 & 290.527 & 1.2984 & RI, DT \\
\hline 11 & 1-Hexanol & 102.2 & 874.2 & 285.871 & 1.3295 & RI, DT \\
\hline 12 & 1-Hexanol dimer & 102.2 & 873.5 & 285.309 & 1.6405 & RI, DT \\
\hline 13 & Butyric acid & 88.1 & 805 & 238.076 & 1.1636 & $\mathrm{RI}, \mathrm{DT}$ \\
\hline 14 & Ethyl butanoate & 116.2 & 793.4 & 231.047 & 1.2082 & $\mathrm{RI}, \mathrm{DT}$ \\
\hline 15 & Dimethyl disulfide & 94.2 & 734.4 & 198.715 & 0.9879 & $\mathrm{RI}, \mathrm{DT}$ \\
\hline 16 & 1-Pentanol & 88.1 & 766 & 215.302 & 1.2556 & RI, DT \\
\hline 17 & 1-Pentanol dimer & 88.1 & 765 & 214.74 & 1.5122 & RI, DT \\
\hline 18 & Acetoin & 88.1 & 711.9 & 188.312 & 1.3309 & $\mathrm{RI}, \mathrm{DT}$ \\
\hline 19 & Hydroxyacetone & 74.1 & 636.7 & 162.727 & 1.2278 & RI, DT \\
\hline 20 & Ethyl acetate & 88.1 & 607.3 & 155.136 & 1.3379 & $\mathrm{RI}, \mathrm{DT}$ \\
\hline 21 & Butanal & 72.1 & 631.4 & 161.321 & 1.2877 & $\mathrm{RI}, \mathrm{DT}$ \\
\hline 22 & Acetone & 58.1 & 502.8 & 129.551 & 1.119 & RI, DT \\
\hline 23 & Ethanol & 46.1 & 448.9 & 116.337 & 1.0493 & RI, DT \\
\hline 24 & 2-Pentanone & 86.1 & 687.2 & 178.472 & 1.3714 & RI, DT \\
\hline 25 & 3-Methyl-3-buten-1-ol & 86.1 & 736.7 & 199.839 & 1.4969 & $\mathrm{RI}, \mathrm{DT}$ \\
\hline 26 & Butyl acetate dimer & 116.2 & 809.1 & 240.606 & 1.6196 & RI, DT \\
\hline 27 & Butyl acetate & 116.2 & 810 & 241.168 & 1.2389 & $\mathrm{RI}, \mathrm{DT}$ \\
\hline 28 & Linalool & 154.3 & 1103 & 660.627 & 1.22 & RI, DT \\
\hline 29 & Hexanal dimer & 100.2 & 791.2 & 229.747 & 1.5584 & RI, DT \\
\hline 30 & Hexanal & 100.2 & 790.2 & 229.155 & 1.2582 & $\mathrm{RI}, \mathrm{DT}$ \\
\hline 31 & 3-Methylbutanal & 86.1 & 663.8 & 170.588 & 1.4034 & RI, DT \\
\hline 32 & Propanoic acid & 74.1 & 750.1 & 206.675 & 1.3583 & RI, DT \\
\hline 33 & Trans-2-hexenol & 100.2 & 849.8 & 267.574 & 1.1794 & RI, DT \\
\hline 34 & Trans-2-hexenol dimer & 100.2 & 850.2 & 267.88 & 1.5165 & RI, DT \\
\hline 35 & 3-Pentanone & 86.1 & 695.8 & 181.713 & 1.3528 & $\mathrm{RI}, \mathrm{DT}$ \\
\hline 36 & 2,3-Pentanedione & 100.1 & 685 & 177.683 & 1.3102 & RI, DT \\
\hline 37 & 2-Methylpropyl acetate & 116.2 & 767.3 & 215.986 & 1.6155 & RI, DT \\
\hline 38 & Ethyl propanoate & 102.1 & 716.9 & 190.482 & 1.4538 & RI, DT \\
\hline 39 & Gamma-terpinene & 136.2 & 1062.6 & 564.372 & 1.217 & RI, DT \\
\hline
\end{tabular}

aRepresents the RI calculated using $n$-ketones $\mathrm{C}_{4}-\mathrm{C}_{9}$ as external standard on FS-SE-54-CB-1 column.

bRepresents the retention time in the capillary GC column.

'Represents the migration time in the drift tube. 


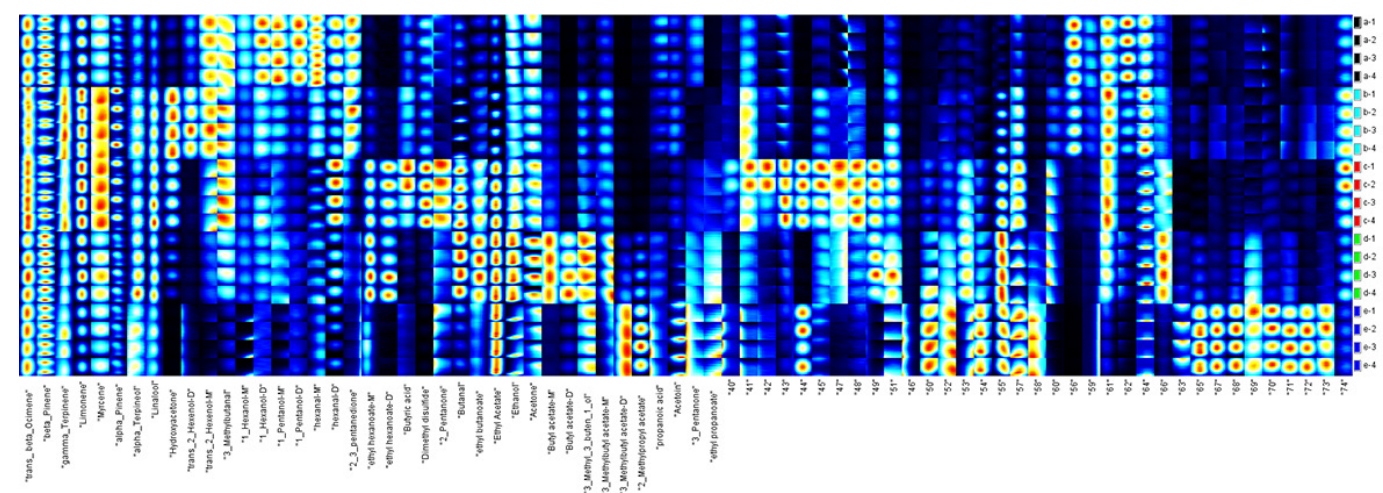

Figure 4. Gallery plot of selected signal peak areas obtained from atemoya fruit flesh at five stages of senescence (a-e, at harvest, $1,3,5$, and 7 days, respectively).

3-methylbutanal, hexanol, and 2,3-pentanedione were much higher in fresh fruit at harvest than in other stages, and gradually decreased during the ripening process, such that only very weak signals were detected at the final storage stage. Increasing volatile compounds were identified as postharvest ripening progressed, alpha-terpineol and linalool contents increased, and acetone and ethanol contents were decreased. Hydroxyacetone, ethyl hexanoate, butyl acetate, butyric acid, and dimethyl disulfide compounds contributed to flavor metabolism during mid-stage storage. As the fruit completely matured and before quality deteriorated, butanal, ethyl butanoate, ethyl acetate, 3-methylbutyl acetate, 2-methylpropyl acetate, propanoic acid, acetoin, 3-pentanone, 3-methyl3-buten-1-ol, and ethyl propanoate were identified, contributing to the typical aroma of the fruit. In addition, many dimers of volatile compounds were observed at different storage stages, with significantly different compositions and levels.

The principal component analysis (PCA) was applied to evaluate the contribution rates of characteristic volatile compounds based on signal intensities. As presented in Figure 5, samples of postharvest atemoya fruit from different ripening stages existed in fully independent spaces and were well distinguished in the score map, demonstrating that the volatile compounds changed markedly through the postharvest storage process. The PCA described $75 \%$ of the accumulative variance contribution rate, with $\mathrm{PC} 1$ and $\mathrm{PC} 2$ describing 47 and $28 \%$, respectively. These volatile fingerprints of atemoya samples at different senescence stages will contribute to the sensory evaluation of this fruit.

\section{Conclusions}

In this work, the peak respiratory and ethylene production rates of atemoya fruit in ambient conditions were observed before physiological maturity on the 5th day, accompanied by a skin color change from dark green to light green or greenish-yellow. The characteristic flavor developed after climacteric respiration, and the fruit was at its best edible condition on the 5 th day postharvest.

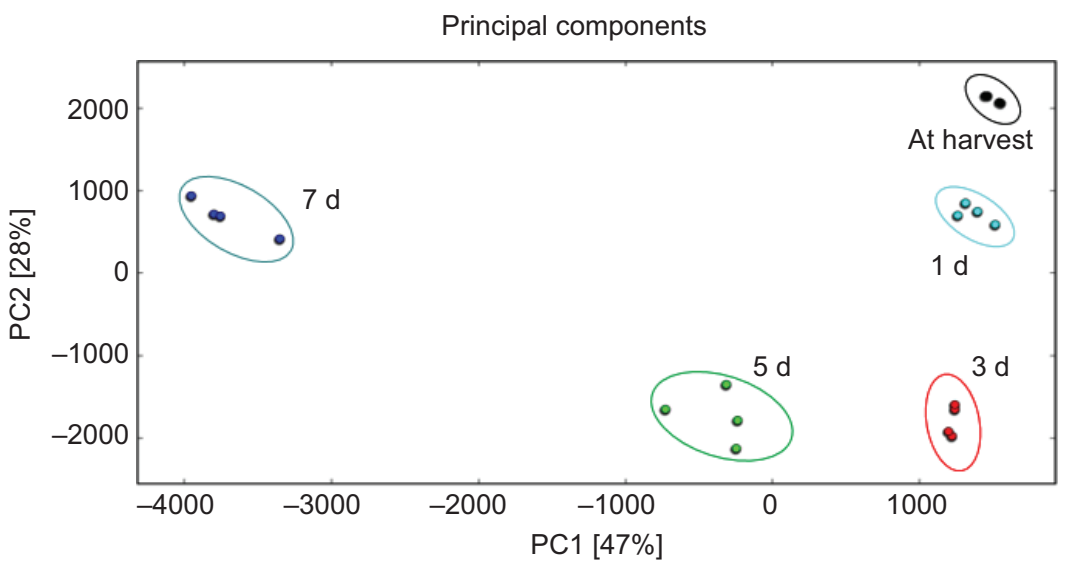

Figure 5. Principal component analysis of postharvest atemoya fruit at five stages of senescence. Results are based on the spectral region at a drift time of $8 \mathrm{~ms}$ and retention time from 90 to $920 \mathrm{~s}$. 
Generally, after 7 days of storage, the fruit had lost almost all commercial value because of softening and skin browning. Based on GC-IMS, the volatile fingerprints from five stages of senescence were successfully established and were successfully distinguished using PCA. The results are expected to provide a theoretical basis for the development of strategies to extend the shelf life of atemoya fruit.

\section{Acknowledgements}

The authors thank Editage (www.editage.cn) for English language editing.

\section{Funding}

Financial support from the Central Public Interest Scientific Institution Basal Research Fund for the Chinese Academy of Tropical Agricultural Sciences (1630122017013), the Innovation Team of Modern Agricultural Industry Technology System in Guangdong Province of China (2019KJ116), and the Earmarked Fund for the Belt and Road Tropical Project (BARTP-10).

\section{References}

Aebi, H., 1984. Catalase in vitro. Methods in Enzymology 105: 121126. https://doi.org/10.1016/S0076-6879(84)05016-3

Ali, S., Khan, A.S., Malik, A.U. and Shahid, M.J., 2016. Effect of controlled atmosphere storage on pericarp browning, bioactive compounds and antioxidant enzymes of litchi fruits. Food Chemistry 206: 18-29. https://doi.org/10.1016/j. foodchem.2016.03.021

Alique, R. and Zamorano, J.P., 2000. Influence of harvest date within the season and cold storage on cherimoya fruit ripening. Journal of Agricultural and Food Chemistry 48(9): 4209-4216. https:// doi.org/10.1021/jf9913561

Bolivar-Fernandez, N., Saucedo-Veloz, C., Solis-Pereira, S. and Sauri-Duch, E., 2009. Ripening of sugar apple fruits (Annona squamosa L.) developed in Yucatán, México. Agrociencia 43: 133-141. https://doi.org/10.1016/j.agee.2008.10.025

Brown, B.I., Wong, L.S., George, A.P. and Nissen, R.J., 1988. Comparative studies on the postharvest physiology of fruit from different species of Annona (custard apple). Journal of Horticultural Science \& Biotechnology 63: 521-528. https://doi. org/10.1080/14620316.1988.11515887

Bruce, R.J. and West, C.A., 1989. Elicitation of lignin biosynthesis and isoperoxidase activity by pectic fragments in suspension cultures of castor bean. Plant Physiology 91(3): 889-897. https:// doi.org/10.1104/pp.91.3.889

Chen, J.J., Duan, Y.J., Hu, Y.L., Li, W.M., Sun, D.Q., Hu, H.G. and Xie, J.H., 2019. Transcriptome analysis of atemoya pericarp elucidates the role of polysaccharide metabolism in fruit ripening and cracking after harvest. BMC Plant Biology 19: 219. https:// doi.org/10.1186/s12870-019-1756-4.

Chu, W.J., Gao, H.Y., Chen, H.J., Fang, X.J. and Zheng, Y.H., 2018. Effects of cuticular wax on the postharvest quality of blueberry fruit. Food Chemistry 239: 68-74. https://doi.org/10.1016/j. foodchem.2017.06.024

Cruz-Bravo, R.K., Guzmán-Maldonado, S.H., Araiza-Herrera, H.A. and Zegbe, J.A., 2019. Storage alters physicochemical characteristics, bioactive compounds and antioxidant capacity of cactus pear fruit. Postharvest Biology and Technology 150: 105-111. https://doi.org/10.1016/j.postharvbio.2019.01.001

Fang, R., Rao, J.Y., Long, X., Huang, W.X., Tang, J., Zhang, J., Zhou, S.Y. and Deng, B., 2015. Introduction performance and cultivation techniques of pineapple custard apple in Chongzuo, Guangxi. South China Fruit (In Chinese) 44(4), 119-121. https://doi.org/10.13938/j.issn.1007-1431.20150256

Galeazzi, M.A.M., Sgarbieri, V.C. and Constantinides, S.M., 1981. Isolation, purification and physicochemical characterization of polyphenoloxidases (PPO) from a dwarf variety of banana (Musa cavendishii, L). Journal of Food Science 46(1): 150-155. https://doi.org/10.1111/j.1365-2621.1981.tb14551.x

Gustavsson, J., Cederberg, C., Sonesson, U., Van Otterdijk, R. and Mcybeck, A., 2011. Global food losses and food waste: extent, causes and prevention. Food and Agriculture Organization of the United Nations, Rome

Gutierrez, M., Sola, M.M., Pascual, L. and Vargas, A.M., 1994. Postharvest changes of sugar concentration in chilled injured cherimoya (Annona cherimola Mill.). Journal of Plant Physiology 143(1): 27-32. https://doi.org/10.1016/S0176-1617(11)82093-6

Hammerschmidt, R. and Kuć, J., 1982. Lignification as a mechanism for induced systemic resistance in cucumber. Plant Pathology 20: 61-71. https://doi.org/10.1016/0048-4059(82)90024-8

Hiwale, S., 2015. Custard apple (Annona squamosa L.). In: Hiwale, S., (ed.) Sustainable horticulture in semiarid dry lands. Springer, New Delhi, pp. 135-152

Horticulture Innovation, 2019. Australian horticulture statistics handbook 2015-2018 (AH15001). Horticulture Innovation Australia Limited Publishing, New South Wales, Australia

Huan, C., An, X.J., Yu, M.L., Jiang, L., Ma, R.J., Tu, M.M. and $\mathrm{Yu}, \mathrm{Z} . \mathrm{F} ., 2018$. Effect of combined heat and 1-MCP treatment on the quality and antioxidant level of peach fruit during storage. Postharvest Biology and Technology 145: 193-202. https://doi. org/10.1016/j.postharvbio.2018.07.013

Koukol, J. and Conn, E.E., 1961. The metabolism of aromatic compounds in higher plants IV. Purification and properties of the phenylalanine deaminase of Hordeum vulgare. Journal of Biological Chemistry 237(5): 1653-1656. http://www.jbc.org/ content/236/10/2692

Krongyut, W., Srilaong, V., Uthairatanakij, A., Wongs-Aree, C., Esguerra, E.B. and Kanlayanarat, S., 2011. Physiological changes and cell wall degradation in papaya fruits cv. 'Kaek Dum' and 'Red Maradol' treated with 1-methylcyclopropene. International Food Research Journal 18: 1251-1259. https://doi.org/10.1016/j. foodchem.2018.05.031

Li, C.R., Shen, W.B., Lu, W.J., Jiang, Y.M., Xie, J.H. and Chen, J.Y., 2009. 1-MCP delayed softening and affected expression of 
XET and EXP genes in harvested cherimoya fruit. Postharvest Biology and Technology 52: 254-259. https://doi.org/10.1016/j. postharvbio.2008.12.009

Lin, Y.F., Lin, Y.X., Lin, H.T., Lin, M.S., Li, H., Yuan, F., Chen, Y.H. and Xiao, J.B., 2018. Effects of paper containing 1-MCP postharvest treatment on the disassembly of cell wall polysaccharides and softening in Younai plum fruit during storage. Food Chemistry 264: 1-8. https://doi.org/10.1016/j.foodchem.2018.05.031

Liu, J., Liu, S., Zhang, X., K, J. and Jin, C., 2019. Effect of gallic acid grafted chitosan film packaging on the postharvest quality of white button mushroom (Agaricus bisporus). Postharvest Biology and Technology 147: 39-47. https://doi.org/10.1016/j. postharvbio.2018.09.004

Magwaza, L.S. and Tesfay, S.Z., 2015. A review of destructive and non-destructive methods for determining Avocado fruit maturity. Food and Bioprocess Technology 8: 1995. https://doi. org/10.1007/s11947-015-1568-y

Morena, J. and De La Plaza, J.L., 1993. The respiratory intensity of cherimoya during refrigerated storage: a special case of climacteric fruit? Acta Horticulturae 138: 179-186. https://doi. org/10.17660/ActaHortic.1983.138.20

Pareek, S., Yahia, E.M., Pareek, O.P. and Kaushik, R.A., 2011. Postharvest physiology and technology of Annona fruits. Food Research International 44: 1741-1751. https://doi.org/10.1016/j. foodres.2011.02.016

Shen, W.B., Li, C.R., Chen, J.Y., Xie, J.H. and Lu, W.J., 2009. Expansin gene expression in cherimoya fruit is correlated with flesh firmness during fruit ripening and softening. Journal of Horticultural Science \& Biotechnology 84: 333-339. https://doi. org/10.1080/14620316.2009.11512527

Suo, J.T., Li, H., Ban, Q.Y., Han, Y., Meng, K., Jin, M.J., Zhang, Z.K. and Rao, J.B., 2018. Characteristics of chilling injury-induced lignification in kiwifruit with different sensitivities to low temperatures. Postharvest Biology and Technology 135: 8-18. https://doi.org/10.1016/j.postharvbio.2017.08.020

Tietz, J.M., 1988. Relacion entre pilosidad del fruto de cherimoya (A. cherimola Mill.) y evolucion de madurez. Tesis Ing Agrícola, Quillota (Chile), Universidad Catolica de Valparaiso'

Ubi, G.M., Onabe, M.B., William, U., Jemide, J.O. and Essien, I.S., 2016. Preliminary studies on fruit lignification time interval and phenological traits of selected okra (Abelmoschus esculentus L. Moench) genotypes grown in Southern Nigeria. Journal of Plant Nutrition and Soil Science 10: 1-10. https://doi.org/10.9734/ IJPSS/2016/23514

Wade, L., 2009. Florida's best fruiting plants: native and exotic trees, shrubs, and vines. By Charles R. Boing. Selbyana 30: 127. https:// doi.org/10.2307/41760357

Zainal, B., Ding, P., Ismail, I.S. and Saari, N., 2019. Physico-chemical and microstructural characteristics during postharvest storage of hydrocooled rockmelon (Cucumis melo L. reticulatus cv. Glamour). Postharvest Biology and Technology 152: 89-99. https://doi.org/10.1016/j.postharvbio.2019.03.001 